\title{
Reclaiming Progressive Realisation: A Children's Rights Analysis
}

\author{
Seamus Byrne \\ Lecturer in Law, School of Law and Social Justice, University of Liverpool, \\ Liverpool, UK \\ Seamus.Byrne2@liverpool.ac.uk
}

\begin{abstract}
Any discussion on children's socio-economic rights should not overlook their means of fulfilment; namely, the principle of progressive realisation and the legal duties arising therefrom. This article argues that from a children's rights perspective, this principle has remained legally and operationally underdeveloped by the Committee on the Rights of the Child. This can be seen from their failure sufficiently to engage with, and address, the obligations imposed by progressive realisation in their General Comments and in their Concluding Observations on state practice issued under the Convention's reporting process. This article argues that the cumulative consequence of these failings is that the Committee has peripheralised this important legal obligation within children's rights scholarship and has ultimately undermined its ability to achieve its full legal potential in enhancing children's socio-economic rights. In advocating for the promulgation of a revised General Comment on the General Measures of Implementation, it demonstrates how children's rights can meaningfully reconnect with the principle in a more consequential way.
\end{abstract}

\section{Keywords}

progressive realisation - general comments - concluding observations - Committee on the Rights of the Child - general measures of implementation

\section{Introduction}

Despite its status as a as 'a relatively young and evolving field of international law’ (Kilkelly and Liefaard, 2019: 618), children's rights law has nonetheless

(C) SEAMUS BYRNE, 2020 | DOI:10.1163/15718182-28040011

This is an open access article distributed under the terms of the prevailing CG BY 4 O license $04 / 26 / 2023$ 03:34:34PM 
exercised considerable influence on international, regional and domestic law and practice (Doek and Liefaard, 2014). However, this article argues that one significant feature of the United Nations Convention on the Rights of the Child (1989) (hereafter the "CRC") has remained legally and operationally underdeveloped, namely, the principle of progressive realisation. Underpinning as it does, contracting states' obligations to fulfil their socio-economic rights commitments, this article argues that the Committee on the Rights of the Child (hereafter "the CRC Committee") have failed to date, sufficiently to engage with, or articulate fully, the obligations flowing from this important principle. This can be seen from their failure to address the obligations which the principle imposes in both their General Comments and in their Concluding Observations on state practice issued under the Convention's reporting process. This article argues that the cumulative consequence of these failings is that the CRC Committee has peripheralised this important legal principle within its treatment of children's rights, thereby undermining its ability to achieve its full legal potential in enhancing children's socio-economic rights. In advocating for the promulgation of a revised General Comment on the General Measures of Implementation to give effect more visibly to the principle of progressive realisation, it demonstrates how children's rights can meaningfully reconnect with the principle in a more consequential way.

This article will be divided into two additional sections. Section two will first examine the principle of progressive realistion by unpacking what it entails and stripping it back to its core identifiable features which are fundamental to its operation and which guide its application in practice. This also allows for an understanding of the legal parameters in which the principle operates. Section three will then analyse the CRC Committee's inadequate engagement with the principle in both its General Comments and Concluding Observations and argue that a revised General Comment on the General Measures of Implementation is necessary to ensure the principle's legal and practical refinement, thereby bringing about much needed operational coherence and visibility.

Despite its firm foothold in international human rights law, the principle of progressive realisation remains opaque. Described as 'a means to an end' (Nolan and Dutschke, 2010: 282) and as a 'necessary flexibility device' (Committee on Economic, Social and Cultural Rights (ComESC), 1990: para. 9), little academic treatment has centred on what the concept specifically entails from a 
children's rights perspective. This lack of definitional clarity has arguably curtailed its conceptual, practical and legal development.

Broadly synonymous with the generation, management and disbursement of domestic state resources to fulfil the realisation of rights such as health, education, housing and social security - rights whose realisation demand an identifiable investment of resources - progressive realisation essentially 'requires that States expand their promotion and protection of economic and social rights over time to the fullest extent possible within their available resources' (Warwick, 2018: 133). Formally legally codified initially in Article 2(1) of the International Covenant on Economic, Social and Cultural Rights (ICESCR), which asserted that states must 'take steps ... to the maximum of its available resources, with a view to achieving progressively the full realization of the rights recognized in the present Covenant by all appropriate means, including particularly the adoption of legislative measures' (emphasis added), the principle finds comparable endorsements in Article 4(2) of the UN Convention on Persons with Disabilities 2006, ${ }^{1}$ Article 3 of the Convention on the Elimination of All Forms of Discrimination Against Woman $1979^{2}$ and Article 4 of the CRC.

Emerging at a time when post-Cold War political and ideological debate surrounding the very purpose of human rights, and specifically socio-economic rights, was at its most intense (Vierdag, 1978: Craven, 1995: Palmer, 2009: Palmer, 2007), progressive realisation signifies the degree of legal and practical latitude which states are afforded in their efforts to realise such rights in light of the economic disparities and resource constraints which exist within and between them. Fredman argues this generates a 'temporal dimension' (2018: 64) to the realisation of such rights in that their fulfilment becomes aligned with the economic capacity of the state in question. This supports Young's contention that progressive realisation 'introduces a relative standard for the discharging of duties owed by the state' (Young, 2012: 101). Indeed, much of the scholarly treatment of progressive realisation has reiterated the dependant and conditional connection between rights on the one hand and resources on the other (Nolan et al., 2014: Kalantry et al., 2010: Young, 2012: O'Connell et al., 2014: Russell and Chapman, 2002). As Fakuda-Parr et al., (2015) assert: 'Inherent in the idea of progressive realization is that a government's ability

1 Article 4(2) states: 'With regard to economic, social and cultural rights, each State Party undertakes to take measures to the maximum of its available resources and ... with a view to achieving progressively the full realization of these rights'.

2 Article 3 states: 'States Parties shall take in all fields, in particular in the political, social, economic and cultural fields, all appropriate measures, including legislation, to ensure the full development and advancement of women, for the purpose of guaranteeing them the exercise and enjoyment of human rights and fundamental freedoms on a basis of equality with men'. 
to fulfil rights commitments depends on the level of resources (financial and other) available in the country' (ibid: 11).

\subsection{Progressive Realisation and the $\mathrm{CRC}$}

From a children's rights perspective, several issues arise when examining the intersection of the CRC and the principle of progressive realisation. First, the CRC itself only makes two explicit textual references to the principle. These include Article 24(4) which, in the context of the right to health, mandates that states, 'promote and encourage international co-operation with a view to achieving progressively the full realization of the right' and Article 28(1), which obligates states to achieve the child's rights to education 'progressively'. Indeed, the most notable provision which engages progressive realisation is itself silent on the principle, namely, Article 4 which states:

States Parties shall undertake all appropriate legislative, administrative, and other measures for the implementation of the rights recognized in the present Convention. With regard to economic, social and cultural rights, States Parties shall undertake such measures to the maximum extent of their available resources and, where needed, within the framework of international co-operation.

Although expressly omitted from the wording of Article 4 CRC unlike its counterpart in Article 2(1) ICESCR, progressive realisation has nonetheless been accepted as integral to its operation with the CRC Committee, stating that Article 4's alignment of socio-economic rights with the issue of resources (financial and otherwise), 'introduces the concept of "progressive realization" of such rights' (CRC Committee, 2003: para. 7). By extension therefore, the principle logically applies to all socio-economic rights within the CRC. However, this has not escaped scrutiny. In her analysis of the drafting history of Article 4, CRC, Nolan (2013) underscores the lack of attention which the principle of progressive realisation received during the CRC's drafting process in comparison to the issue of resources, which she recalls was a 'consistent preoccupation with the CRC drafters' (ibid:: 259). In highlighting further the 'heavy reliance' (ibid.: 254) which the Committee have placed on the work of the Committee on Economic, Social and Cultural Rights in their delineations of the obligations flowing from Article 2(1), ICESCR, despite the linguistic differences between both treaties, a fact recently endorsed by Tobin (2019), Nolan's concerns prompt a deeper interrogation of the legal and practical consequences which flow, from a children's rights perspective, of the Committee's failure adequately to engage with progressive realisation. Before turning to 
consider these, it is first necessary to unpack the core features which underpin the principle and guide its application in practice.

\subsection{Unpacking Progressive Realisation}

\subsubsection{The Obligation 'to take steps'}

The first discernible and immediate obligation for states in furtherance of their duty to progressively realise socio-economic rights is 'to take steps' towards that end (Sepulveda, 2003: Porter, 2015). And while the CRC does not expressly refer to the obligation to 'take steps', its counterpart in Article 2(1) of ICESCR clearly does. Given the conceptual and legal overlap between Article 4, CRC and Article 2(1), ICESCR, coupled with the negligible consideration which progressive realisation received during the CRC's drafting process, a reasonable inference can be made that the taking of steps is a necessary and inferred element of Article 4, CRC. Indeed, it is axiomatic that progressive realisation would become ineffectual in the absence of such a duty. As Tobin (2019) states: 'Anything less would undermine the substantive content of the obligation to take appropriate measures' (ibid.: 141) pursuant to Article 4, CRC. States are expected to 'move as expeditiously and effectively' (Committee Economic, Social and Cultural Rights, 1990) as possible and take 'deliberate, concrete and targeted' (ibid.: para. 2) measures towards the 'achievement of the full scope and content of the right' (O'Connell et al, 2014: 67) in question.

This first requirement represents a critical starting point as the assumption of such steps, be they legislative, budgetary, procedural or otherwise, will invariably differ between rights. Thus, the nature and delivery of these steps requires sustained engagement by states with both the substantive and procedural aspects of the right in question. The right to education illustrates this. Multi-faceted in nature, it comprises rights to education, rights in education and rights through education (Verhellen, 1993: Lundy, 2012: Lundy and O'lynn, 2019). Unpacking these elements further, the legal requirements to satisfy each component become more nuanced. The right to education requires that states ensure education is available, acceptable, accessible and adaptable (Tomasevski, 2001, ComESC Rights, 1999) while rights in education span an array of issues and entitlements to ensure that children have their rights upheld within the educational establishment (CRC Committee, 20o1). This may include, for example, states enacting laws to abolish corporal punishment within schools (CRC Committee, 2006; Stalford and Byrne, 2018) or the strengthening of procedural rights for children when a school's disciplinary procedures are activated. Similarly, rights through education recognise the significance which education plays in the inculcation of those skills which enable young people to live and participate within society (CRC, Art. 29; Lundy, 2006). 
This may require ongoing curricular engagement, consultation and modification to ensure the delivery of these important objectives.

Critically, however, and from a children's rights perspective, such steps should also align with the CRC's four general principles which have created an enduring legal connection between Convention rights on the one hand and their means of delivery on the other (Lundy and Byrne, 2017: Peleg, 2018). Such implementation requirements not only set the CRC apart from the ICESCR but also highlight the need for the CRC Committee to give effect to these legal and practical points of differentiation, and implementation, within its guidance to states regarding the principle of progressive realisation.

\subsubsection{Minimum Core Obligations}

Closely connected with the concept of taking steps to satisfy the requirements of a given right is the notion of the minimum core content of socio-economic rights. This represents the identification and satisfaction of those minimum essential levels - the baseline position - to ensure each socio-economic right is realised (ComESC Rights, 1990). As Chapman and Russell (2002) state, the minimum core comprises 'the nature or essence of a right ... without which [the right] loses its substantive significance' (ibid.: 9) or what Fisher (2017) calls 'a quantitative and qualitative floor ... that must be immediately realized by the state as a matter of top priority' (ibid:: 1). In its endorsement of adopting a minimum core approach pursuant to the ICESCR, the ComESC Rights (1990) states that: 'If the Covenant were to be read in such a way as not to establish such a minimum core obligation, it would be largely deprived of its raison d'etre' (ibid: para. 10). Correspondingly, in its support of the minimum core approach, the CRC Committee have stated that it stands 'parallel to the concept of progressive realization' (CRC Committee, 2007: para. 48) and that satisfaction of such minimum levels of enjoyment are integral for a dignified existence (ibid.). More crucially, however, is the articulation by the Committee that the realisation of the minimum core content of rights is not subject to, or dependant on, the availability of resources (ibid.). This unequivocal support for the immediacy of establishing essential baseline standards is an important step towards the progressive realisation of children's socio-economic rights, for it ensures a demonstrable legal and practical foundation upon which subsequently to improve. Indeed, writing in the context of the right to health (though of wider application), Forman et al. (2016) argue that the development of an 'inviolable "core"' (ibid.: 531) precludes 'progressive realisation within resources from undermining both domestic and international responsibilities towards health' (ibid.).

However, the minimum core approach has not eluded debate. Questions arise about what exactly constitutes the minimum core itself and whether all 
states can be expected to implement equivalent approaches considering their economic disparities (Chapman and Russell, 2002: Young, 2008). Warnings have also been expressed that the approach may engender a purely minimalist attitude to the realisation of socio-economic rights (Young 2008), that it is too 'utilitarian' and ill-suited to individual needs (Lehmann, 2006) or that the protective floor which it seeks to establish would actually become a 'ceiling' in terms of the level of enjoyment of the right in question (Chapman and Russell, 2012: 9). Although much academic treatment has focused on establishing either the minimum core content of each right (Chapman and Russell, 2002: Eide, 1995: Young, 2008) or the utility of adopting such an approach (Bilchitz, 2003: Tasiolas, 2017: Shields, 2017), it is important not to conflate a right's minimum core with progressive realisation. In its most reductionist form, the minimum core directs the establishment of an identifiable starting point for any given right while progressive realisation mandates the taking of steps from this starting point. In the context of the right to education, minimum standards dictate that primary schooling should be made freely available to all with secondary, vocational and higher education subject to progressive realisation (Art. 28, CRC). However, the entry point at primary level for children with special educational needs (SEN), for example, will vary enormously from their non-SEN peers. Their minimum core prerequisites may require the provision of special needs assistants, the adaption of the educational premises to meet their needs and/or the modification of both the content and delivery of the curriculum to meet their specific educational requirements. As Leckie (1998) argues: 'Identifying minimum core contents, as well as the minimum core obligation of states to secure such rights, must be seen as only the first step, rather than the conclusion of a process' (ibid.: 102). In other words, a right's minimum core does not satisfy the obligation progressively to realise it. Rather, properly assessed, it provides a starting point from which to progress from.

\subsection{3 "Maximum Available Resources"}

Any discussion on the principle of progressive realisation must also appreciate the legal and, indeed, resource constraints within which it operates (Kendrick, 2017). Human rights law recognises this by precluding an absolutist approach to the principle of progressive realisation. From a children's rights perspective, Article 4, CRC mediates the principle's application along two legal tracks. First, in what can be described as an immediate internal obligation, states are under a requirement to use the 'maximum extent of their available resources' to realise their socio-economic rights commitments. Failing this, the secondary external aspect of Article 4 becomes operational in that such rights become realisable 'where needed, within the framework of international cooperation' 
(CRC, Article 4(2)). Therefore, possessing both an internal and external dimension, Article 4, CRC clearly engages both the doctrine of "maximum available resources" and the notion of "international cooperation".

With regards to the doctrine of "maximum available resources", Robertson asserted that it represents:

two warring adjectives describing an undefined noun. "Maximum" stands for idealism; "available" stands for reality. "Maximum" is the sword of human rights rhetoric; "available" is the wiggle room for the state (1994: 694).

Robertson further outlines what he identifies as the 'most important resources' (ibid:: 697) in achieving socio-economic rights as: 'financial, natural, human, technological, and informational' (ibid.). In one of its earliest general comments, the ComESC Rights stated that the phrase "maximum available resources" referred to "both the resources existing within a State and those available from the international community through international cooperation and assistance' (1990: 13). This broad dualist construction, and the extra-territorial dimension to resources, has further been elaborated through the 1987 Limburg Principles on the Implementation of the International Covenant on Economic, Social and Cultural Rights, the 1997 Maastricht Guidelines on Violations of Economic, Social and Cultural Rights and the 2011 Maastricht Principles on Extraterritorial Obligations of States in the area of Economic, Social and Cultural Rights, all of which assert that states have a direct obligation to mobilise existent resources, both within and outside the state, in furtherance of their socio-economic commitments. From a children's rights perspective, the Committee have further stated that the notion of resources encompasses 'human, technological, organizational, natural and information resources' (CRC Committee, 2007: para. 24) and further that resources should 'be understood in qualitative terms and not solely quantitative' (ibid.).

However, states' deployment of financial resources is perhaps the most obvious signal of a commitment to a socio-economic initiative. Indeed, it is the intersection of finance and human rights which has generated much academic scholarship (Centre for Woman's Global Leadership, 2011: Nolan, 2013: Murphy, 2017: Kendrick, 2017: O'Connell et al., 2014). Central to that work has been the recognition that given the limited nature of resources, and specifically financial resources, the application of a human rights framework to budgetary decisions can direct much needed resources into priority and high-risk areas. From a children's rights perspective, this intersection culminated in the CRC Committee issuing a General Comment in 2016 on the specific topic of public budgeting for the realisation of children's rights. In particular, the Committee 
noted that despite the significant efforts made by contracting states in aligning their domestic policies and procedures with the rights enshrined therein, 'such legislation, policies and programmes cannot be implemented without sufficient financial resources being mobilized, allocated and spent in an accountable, effective, equitable, participatory, transparent and sustainable manner' (CRC Committee, 2016: 11) (emphasis added). In the context of utilising all 'maximum available resources', the Committee outlines that states must not only demonstrate that they have adopted all relevant and appropriate measures to mobilise, generate, allocate and spend budget resources in furtherance of children's socio-economic rights, but also that they have avoided any deliberate retrogressive steps in pursuance of such an objective (ibid.: 28-35).

In her analysis of how best to use 'maximum available resources', Skogly (2012) argues that the current approaches largely follow a quantitative financial schema; namely, what money and how much of it is directed towards a particular public service or facility. In calling for a shift towards a more qualitative approach, Skogly calls not only for a more thorough understanding of what is meant by "resources" but also, critically, for a fundamental re-imagination of the way those resources are administered. By examining the means of implementation, and the policies and procedures which guide them, she argues that 'much can be achieved without necessarily requiring a significant increase in funding'" (ibid.: 405). Indeed, Skogly's call for administrative ingenuity is important for two reasons. First, as resources are often limited, new approaches and methodological designs for their disbursement can enhance their widest possible reach. For example, the use of children's rights impact assessments (CRIA s), which seek to foreground children's rights within regulatory decision-making about how best to distribute limited resources, can provide a robust foundation to justify investment in a particular socio-economic area (UNICEF, 2013). Through their targeted and pointed configuration, CRIA s are vital procedural safeguards in ensuring children's rights are foregrounded within policy formation (CRC Committee, 2013). They could also potentially ensure that the principle of progressive realisation is incorporated within policy processes such that any proposed legislative, administrative, budgetary or procedural enactment would be considered against its capacity to further realise children's rights. In this regard, much potential exists to recalibrate fundamentally existent and future approaches to CRIA s so that they include progressive realisation as a point of analysis in their determinations of the compliance of a proposed measure with children's rights.

Secondly, by moving away from purely fiscal approaches to what is meant by using 'maximum available resources', children's socio-economic rights can still be progressively realised by adhering to the CRC's four general principles: 
non-discrimination (Article 2), the best interests principle (Article 3), the right to life, survival and development (Article 6) and the right to participate (Article 12). In the context of progressive realisation, they can inform and frame the disbursement of resources and bring a procedural legitimacy to such actions. Indeed, given that the CRC Committee have previously stated that the issue of resources should also be understood in "qualitative" (CRC, 2007, para. 24) terms, the question therefore arises as to the exact legal and practical obligations which flow from this statement. What exactly is meant by "qualitative resources"? How are they generated, mobilised and distributed? And from an accountability perspective, how do states elucidate that they have given effect to, and adhered to the requirements emanating from, qualitative resources? Should this be understood purely in participatory terms or does the reference subsume the broader procedural obligations identified by O'Connell et al., (2014) which include effectiveness, participation, accountability, transparency and equality which, they argue, 'are identified principles that are aspects of the duty to progressively realise' socio-economic rights (ibid.; 69). While this highlights that adherence to the "maximum available resources" principle also involves engaging with other non-fiscal measures, including procedural protections, to progressively realise children's socio-economic rights, it also demonstrates the need for the CRC Committee to more fully and expansively engage with the issue of resources and their relationship with the principle of progressive realisation.

\subsection{4 "The Framework of International Cooperation"}

Dealing next with the external dimension to Article 4, CRC, the duties which flow from the obligation to provide international cooperation are arguably defined by their legal ambiguity. In generalist terms, the concept reflects the reality that the realisation of socio-economic rights, on a universal level, and within particular states, will not materialise in many instances, without international bi-lateral or multilateral support (Karimova: 2014). Within such a context, cooperation (and assistance) and the degree thereof expected of states will invariably differ between them on account of their economic development (Sepulveda: 2006). Unlike its counterpart in Article 2(1), ICESCR, the CRC only refers to international cooperation and not assistance. Encapsulated within Article 4, CRC and expressed within other socio-economic provisions such as health (Article 24(4)) and education (Article 28(3)), the duties imposed by "international cooperation" have not, however, been satisfactorily delineated by the CRC Committee. Rather, opaque articulations have characterised their treatment of the framework of international cooperation. 
In General Comment No. 5 on the General Measures of Implementation, the CRC Committee stated that: 'when States ratify the Convention, they take upon themselves obligations not only to implement within their jurisdiction, but also, to contribute, through international cooperation, to global implementation' (CRC Committee, 2003: para 7). Similarly, they have stated that 'children's rights are a shared responsibility between the developed and the developing countries' (CRC Committee, 2007: paras. 50-51). While such comments reflect a well-founded and admirable desire to ensure that children's rights are realised globally, they do little, however, to define or advance the legal obligations, if any, which Article 4, CRC contains with respect to international cooperation. The absence of such clarity, therefore, opens up a contestable legal space whereby the precise contours of "international cooperation" remain indeterminate which potentially undermines global efforts to realise children's rights. In his examination of the outputs of the CRC Committee, Vendenhole (2009) concluded that the CRC Committee have abstained from establishing a general duty in the area of providing development cooperation but given that such cooperation does however take place, they have established a number of obligations which should be adhered to within such a framework. These include the need for countries to use the $\mathrm{CRC}$ as an overarching evaluative guide when providing assistance and to mainstream a child-rights based approach in the adoption and implementation of developmental programmes and plans (ibid: 56-47). Moreover, although the CRC Committee do refer to international cooperation in General Comment No. 5 and outline a number of suggestions including that states abide by internationally agreed development goals and targets, use international technical assistance when required and that recipient states allocate a substantive portion of such support for the implementation of children's rights, the guidance is otherwise tentative and elusive. It neither prescribes states comprehensively to delineate the expenditure to track the progressive realisation of children's rights, nor do the treaty reporting guidelines expand on this (CRC Committee, 2015: para. 19 (E)). Rather, the precise legal nature of "international cooperation" remains vague and indeterminate.

More problematically, and as recently observed by Tobin (2019), the CRC Committee have been unclear regarding whether the framework of international cooperation extends to all classification of human rights or whether it is merely confined to economic, social and cultural rights. Indeed, Tobin highlights, that despite the fact that an ordinary consideration of Article 4, CRC would suggest such a confinement, this would, in practical terms, result in an 'incongruity' (ibid.: 144) and would defeat the accepted 'artificiality of the distinction between both sets of rights' (ibid.). Tobin's further development of the obligations imposed by the framework of international cooperation by 
adopting the 2011 Masstricht Principles on Extraterritorial Obligations of States in the Area of Economic, Social and Cultural Rights as an evaluative legal frame to unpack what "international cooperation" legally entails further exposes the need for clarity by the CRC Committee on this issue and the need for a more rigorous and detailed articulation of the legal obligations expected of sates both donor and recipient - within the context of international cooperation.

\subsubsection{Non-Retrogression}

Described as a 'major component' (Wills and Warwick, 2016: 654) of the principle of progressive realisation, the implied principle of non-retrogression assumes critical importance when assessing state obligations regrading socio-economic rights. Acting as a legal backstop, it aims to prevent against any deliberate reversion in existent levels of rights enjoyment. The ComESC Rights (1990) has stated that any such retrogressive measures 'would require the most careful consideration and would need to be fully justified by reference to the totality of the rights provided for in the Covenant and in the context of the full use of the maximum available resources' (ibid.: para. 9). In their examination of the principle, Nolan et al. (2014) identify two distinct dimensions underpinning its operation, namely a normative and an empirical dimension. The former, they argue, concerns the prohibition of retrogressive measures in terms of 'legal de jure guarantees'. This examines whether there has been a diminution or reversion in the level of entitlement given by a specific legal norm (ibid:: 123). The latter, they argue, relates to 'de facto, empirical backsliding in the effective enjoyment of rights' (ibid.) which examines the actual enjoyment of the right in question. They further argue that establishing whether retrogression has occurred requires an 'evidential link between particular state conduct on the one hand and the factual outcome of decreased rights enjoyment on the other' (ibid.: 128) supported by 'sophisticated statistical and other information' (ibid.). However, the principle is not absolute and retrogressive measures are permissible, albeit within constricted parameters (ComESC, 2012). Such measures must be temporary, necessary and proportionate, reasonable and non-discriminatory, must not disproportionally impact the rights of marginalised groups and must protect the minimum core content of rights (ibid.: Nolan et al., 2014). Ascertaining whether any de jure or de facto "backsliding" has occurred requires ongoing monitoring by contracting states. Indeed, Nolan et al. (2014) argue that: 'Measuring the extent of progressive realization requires information on the extent to which obligations are realized in relation to specific groups' (ibid:: 69). Moreover, the potential which the principle of non-retrogression assumes was succinctly captured by Warwick (2019) who stated that ultimately it 'ties States to what they have already achieved' (ibid.: 471) 
and which could, 'if fully functional - protect a virtuous cycle of human rights improvement' (ibid.). Therefore, any retrogressive practices which negate or reverse the de facto or de jure enjoyment of children's socio-economic rights must be scrutinised and considered against the principle of progressive realisation and the connected obligations arising from non-retrogression. However, despite the rich academic scholarship on the doctrine of non-retrogression, its position within children's rights law has not been as observable or indeed influential. Rather, the doctrine has received limited attention by the CRC Committee despite the important legal role it assumes within the realisation of children's socio-economic rights.

\title{
2.2.6 Non-Discrimination
}

Although not directly a constituent element underpinning the progressive realisation of socio-economic rights per se, progressive realisation is subject to full compliance with the principle of non-discrimination (Chapman and Russell, 2002) and, as a general principle underpinning the CRC, it plays a decisive role in ensuring the equal delivery of children's rights. As the Committee on the Rights of Persons with Disabilities recently stated:

Equality and non-discrimination are among the most fundamental principles and rights of international human rights law. Because they are interconnected with human dignity, they are the cornerstones of all human rights (UN, 2018: para. 4).

Similarly, the ubiquity of non-discrimination clauses at both supra-national and regional level attest to the fact that it underpins and unites the operation and delivery of all classification of rights: civil, political, economic, social and cultural (McNaughton, 2018: Human Rights Committee, 1989). From a children's rights perspective, the principle of non-discrimination occupies an elevated position in that, as a general principle, all rights contained within the CRC must be delivered in an equal non-discriminatory manner, while simultaneously amounting to an individual compellable entitlement in its own right (Abramson, 2008: Besson, 2005).

\author{
The Case for Updating General Comment No. 5: Elaborating the \\ Duty Progressively to Realise Children's Rights
}

Having discussed the core features which frame and guide the application of the principle of progressive realisation, this section now turns to examine 
the reasons why the CRC committee should revise General Comment No. 5 on the General Measures of Implementation to more adequately and visibly give effect to the principle of progressive realisation. Three reasons underpin this. The first of these relates to the failure by the CRC Committee adequately to engage with progressive realisation within its General Comments (GC s). The second and related reason pertains to the inability of GC s No. 5 and No.16 (on Public Budgeting) to fully elaborate the legal and practical ramifications which stem from progressive realization while lastly, the third reason revolves around the failure of the Committee to consider progressive realization within the Concluding Observations issued pursuant to the CRC'S reporting process. The net effect of such failings is that the CRC Committee has contributed to the principle's under-development within children's rights law (Nolan, 2013), and if left unremedied, could potentially curtail the effective implementation of children's socio-economic rights.

\subsection{The CRC's GC s Inadequate Engagement with Progressive Realization}

The first notable area where the CRC Committee's disengagement with progressive realisation can be seen is in the guidance issued though its GCs. Despite the non-binding nature of such comments (ILA, 2004) and their mutable status within the international legal order, treaty-based GCs nonetheless 'play a substantive role in the elaboration of standards and possible future custom within the complex matrix of international law' (Gerber et al., 2013: 101). From a children's rights standpoint, the GC's are very much the jewels in the Committee's crown as they delineate the core baseline expectations and specificities which attach to the realisation of the various rights within the CRC. Although 'auxiliary to treaty obligations' (Bodig, 2016: 69) and bereft of legal force, they exert a growing level of influence on international human rights law, not least as increasingly popular sources of reference in both domestic and supra-national jurisprudence (McCall-Smith, 2016). In the UK, for example, the GC $s$ have been frequent points of judicial reference in a wide range of cases where children's rights have been engaged. In ZH Tanzania v. Secretary of State for the Home Department ${ }^{3}$ the Supreme Court, per Lady Hale, drew extensively on GC No. 6 (2005) on the Treatment of Unaccompanied Minors and Separated Children Outside their Country of Origin to construe the best interests principle in conjunction with domestic immigration legislation. Thus, their interpretive value cannot be underestimated.

3 [2011] UKSC 4. 
Explanatory in their composition, they 'address in a comprehensive fashion the substantive content of some of the major rights' (Alston, 2010: 5) within human rights treaties. However, their impact beyond the mere amplification of the core legal and textual content of rights is perhaps where their true potency lies. As Bodig (2016) argues, they 'offer the opportunity of securing a foothold within the UN system for more progressive interpretation of human rights norms' (Bodig, 2016: 70) and 'can be more responsive to the ever-shifting challenges of human rights protection' (ibid.). Undoubtedly, in the context of children's rights, one such challenge is to ensure the progressive realisation of children's socio-economic rights within a vastly transformed legal, political and socio-economic climate where the ascendancy of neoliberalism (Moyn, 2018: McNaughten and Frey, 2018), the political normalisation of austerity (Saiz, 20og: Bilchitz, 2014), the consequential rise of privatisation (UN, 2018: Nolan, 2018) and the outsourcing and sub-contraction of children's public services to private operators (Stalford, 2019), converge to directly challenge, and in some instances, undermine, the realisation of children's rights socio-economic rights.

A review of the 25 GC's thus far issued by the CRC Committee reveals that their engagement with progressive realisation is negligible. Of the five which substantively address socio-economic rights, three are devoted to health (GC s Nos 2, 14 and 15), one addresses the aims of education (GC No. 1) and the remainder centres on the right to rest, leisure, play, culture and the arts (GC No. 17). In all five, minimal reference is made to progressive realisation. Indeed, the Committee's engagement with the procedural aspects of state obligations in its GC s, such as meaningfully ensuring child participation across all socio-economic areas, fails to connect them with the principle of progressive realisation. In its GC on Public Budgeting (2016) and in the recommendations issued after the Day of General Discussion on the issue of Resources and the Responsibility of States (2007), their engagement with progressive realisation was also nominal. While both documents do refer to "progressive realization", the former does so in a superficial manner, effectively restating that the rights contained within the CRC are contingent on the principle in certain circumstances. The latter, while acknowledging that the concept is often misunderstood, reasserts that progressive realisation requires States to take targeted measures towards the realisation of socio-economic rights with duties such as non-discrimination taking immediate effect (ibid.: para 47). Similarly, in the GC on the General Measures of Implementation (CRC Committee, 2003), the Committee again fails to engage with progressive realisation. Although outlining the need for policies and practices to bring Contracting States into line with their obligations, the Committee's singular reference to progressive 
realisation (ibid:: para 7) exists as a peripheral reflection. Furthermore, in its GC on Implementing Children's Rights in Early Childhood (GC No. 7, 2005), the Committee is entirely silent on progressive realisation. Although they outline detailed recommendations on the need for States to develop national strategies rooted in the Convention and to encourage cross departmental coordination of children's rights, in addition to ensuring the collection and assessment of sufficient and reliable quantitative and qualitative data regarding the realisation of children's rights, such recommendations, though important, are devoid of any meaningful correlation with the duty progressively to realise the rights contained within the CRC. This is significant as such guidance relates to the establishment of the overarching structures necessary to achieve an adequate rights-supporting infrastructure within contracting states and in many respects reflect the obligation "to take steps". However, they are not in and of themselves tantamount to the progressive realisation of children's socio-economic rights.

Consequently, the result of the Committee's failure to engage with progressive realisation is that it ultimately generates a legal and practical disconnection between the right itself and its means of realisation. In other words, rather that illuminating and centralising the principle's guiding features within its guidance, their treatment of progressive realisation in almost separate and inchoate terms, possesses the potential critically to undermine the development and realisation of children's socio-economic rights. And for those who possess an awareness of broader socio-economic rights law or who can disentangle the legal, conceptual and vocational overlap between the CRC Committee and the work of the Committee on Economic, Social and Cultural Rights, this might not prove overly problematic. But for stakeholders who perhaps principally rely on the CRC's guidance, the marginal treatment of progressive realisation could prove problematic in terms of enabling them to hold states accountable for their obligations. For instance, in its very first General Comment on the quality and purpose of education (2001), no reference was made to addressing the progressive realisation of the right to education in all of its facets, procedural and substantive, despite Article 28, CRC stipulating that states must achieve the right 'progressively' (Art. 28(1), CRC). Although outlining the significance of education for child development, the Committee position their comments almost exclusively within the context of Article 29, CRC which expounds the purpose of education. It does not comprehensively address the requirements of Article 28, CRC which first guarantees the right to education. Although the committee do refer to the principle of non-discrimination, they do not engage with nor amplify the connected requirements for states to 'take steps' to realise the right, to use their 'maximum available resources' in so doing and to 
ensure that children do not suffer any retrogression in the enjoyment of their rights. In essence, the CRC Committee sidestep their obligations to outline the obligations flowing from Article 28(1) which mandates states to achieve the right 'progressively'. If children's socio-economic rights are to have real meaning, then their concomitant means of delivery, namely progressive realisation, must also entail enforceable consequential measures. As Felner (2009) argued,

circumventing the standard of progressive realization has severely constrained the ability of the human rights movement to hold governments accountable for policies and practices that turn millions of people into victims of avoidable deprivations such as illiteracy, malnutrition, preventable diseases, and homelessness (2009: 402).

\subsection{The Limitations of General Comments No. 5 and No. 19}

Closely connected with the CRC Committee's failure to incorporate progressive realisation within its GC $s$ is the failure of GC No. 5 on the General Measures of Implementation and GC No. 19 on Public Budgeting sufficiently to give effect to progressive realisation within their guidance. Undoubtedly GC s No. 5 and No.19 represent critical consultative and procedural directives for ensuring the effective implementation of the CRC into domestic legal systems. However, on closer inspection they do not fully address the core obligations which fall under the principle of progressive realisation. As a carefully calibrated legal principle designed to placate the tensions between a state's economic capacities, their allocative autonomy and the obligations arising under socio-economic rights law, progressive realisation warrants considerably more engagement than that which it currently receives under GC s No. 5 and No. 19. Looking firstly at GC No. 5 , the need for updated guidance becomes apparent. Introduced in 2003, it firstly commences with a heavily caveated foreword which professes the "complex" (CRC, 2003) nature of the CRC's general measures of implementation and secondly with an admission of the Committee's intention to issue more 'detailed guidance of individual elements in due course' (ibid.). While Collins (2019) has described the CRC's general measures of implementation as a 'useful, practical framework to facilitate the realisation of child rights' (ibid.: 339), it is nonetheless important to appreciate that GC No. 5, even by the Committee's own stated intentions, is by far a fault proof or finalised implementation manual. Despite the singular textual reference to progressive realisation (2003: para. 7), it fails to expound what is meant by progressively realising children's socio-economic rights or what Ssenyonjo calls the 'obligation to ensure that the steps taken are geared towards the obligation of result which is 'achieving progressively the full realisation' of ESC rights' (Ssenyonjo, 2011: 977). In 
other words, it fails expressly to state that the actions and steps which states are expected to take must progressively realise the socio-economic rights contained within the CRC. Such steps must also reflect, and remediate where necessary, the specific plight of children and the unique social, legal and political position they occupy. Nolan (2013) argues that factors such as children's heightened vulnerability to violations, their inability to secure special rights for themselves, the impact which violative actions exert on them in the short and long term, their difficulty in vindicating their socio-economic rights, the additional vulnerabilities which some children face through membership of pre-existing minority groups, the need to give effect to their evolving capacities and their reduced ability to advance rights claims in comparison to adults, all converge to set children apart, by virtue of being children, regarding the enjoyment (or non-enjoyment) of their socio-economic rights (ibid.: 250-252). Such realities not only underscore the need for detailed elaboration about how progressive realisation intersects with children's rights specifically but also the need for the CRC Committee to move beyond their reliance on the work of the Committee on Economic, Social and Cultural Rights whose legal focus is of a much more general nature.

Moreover, on the issue of resources, which are integral to the principle's operation, the Committee's treatment of what is encapsulated within the phrase itself is conceptually limited and legally underdeveloped. Their allusion to 'financial resources and other resources' (CRC Committee 2003: para. 7) within the context of the general measures of implementation lacks any explanation of what is meant by "other resources" and how these are to be mobilised and distributed. And although a more expansive interpretation of resources was adopted in their 2007 Day of General Discussion, the primacy of GC No. 5 within the Committee's reporting system and its corresponding reporting guidelines do not reflect the Committee's more enlarged conception of resources. Similarly, and perhaps more problematically, the Committee's reference to qualitative resources as discussed earlier warrants further clarification. In its absence, the potential which this prospective body of resources could bring to bear on the obligations of states to fulfil children's rights is severely constrained. While financial resources are, of course, the primary determinant in the realisation of socio-economic rights, they are not the sole aspect of such an endeavour. In this regard children's rights scholarship and the labour of the Committee should caution against any dismissive treatment of so called "other resources".

Relatedly, the Committee's failure to interrogate what is meant by the concept of 'maximum available resources' beyond the inconsequential restatement of its alignment with progressive realisation (CRC, 2003: Foreward, paras. 
6, 7 and 51) further possesses the capacity to dilute the obligations of states towards realising children's socio-economic rights. The Committee's passing references to it divest it of its critical significance for they fail to acknowledge the manifold 'pools from which resources can be drawn' (Kendrick, 2017: 662). For example, in his discussion of the importance of "social resources" (Ssenyonjo, 2011: 980); namely those which are 'mobilised by the widest possible participation in development, as necessary for the realisation by every human being of ESC rights' (ibid.), Ssenyonjo reminds us of the importance which non-fiscal resources play in the progressive realisation of socio-economic rights. It also underlines the need for more updated guidance on this issue from a children's rights perspective. Thus, the narrow and largely monetary approach to resources which GC No. 5 currently adopts and prioritises, reflects a legal myopia, the manifestation of which is distinctly inimitable to the pronounced procedural safeguards which children's rights have meticulously cultivated over the years. As O Connell et al. (2014) have argued: '... the content of the duty to realize progressively is not just about the positive actions that have to be taken but also about the process through which decisions regarding those actions are taken' (ibid.: 69). Moreover, the confusion regarding the legal contours within which the "framework of international cooperation" operates and its connection with the issue of resources and the wider extra-territorial dimension to the realisation of socio-economic rights, warrants updated clarity by the CRC Committee. Failure to do so prolongs the legal ambiguity which currently surrounds it.

Similarly, the complete absence of any reference to the principle of non-retrogression, the legal and practical corollary of progressive realisation represents a striking anomaly within GC No. 5 . Described by Warwick as a doctrine requiring 'urgent' discussion (2019:468), its absence from GC No. 5 is noteworthy for it removes an important layer of legal protection for children's socio-economic rights from the lexicon, and indeed operable reach, of children's rights law. As discussed earlier, its function as a legal backstop plays a critical role in preventing against the de jure and de facto reversion in the enjoyment of socio-economic rights. However, the doctrine of non-retrogression has itself not evaded critique. In her examination of the intersection of human rights, economics and austerity, Dowell-Jones (2015) argues that current global fiscal realities have exposed serious limitations within the international socio-economic rights-based framework. Specifically, her argument that well-established principles such as non-retrogression and progressive realisation, 'are simply not sufficient to address the very critical challenges of solvency and fiscal sustainability that welfare systems in the advanced economies now face' (ibid.: 212), demands broader scrutiny of both the contours and context within which such 
principles operate. Whilst such principles have demonstrably failed to push back against austerity, that failure is arguably not attributable to the principles themselves, but rather with their conceptual and legal underdevelopment, and practical application, by the broader human rights community. As Wills and Warwick (2016) argue, such principles, 'can serve as important counterframes to the dominant neoliberal fixation on competitiveness, efficiency and economic rationality' (ibid.: 631). Thus, the centrality of non-retrogression as an inseparable legal corollary of progressive realisation is beyond doubt. It therefore requires detailed elaboration by the CRC Committee to imbue it with its full legal potential.

Regarding GC No. 19, its primary limitation is perhaps the unintended consequence of its explicit thematic focus. Coming 13 years after GC No. 5 , it exclusively situates state obligations within the realm of public budgeting and aims to embed children's rights within such processes. With its emphasis, therefore, on the broader fiscal approaches towards realising children's rights, it does not engage with non-fiscal resources and/or approaches which also apply to the progressive realisation of children's rights. Although the comment does indeed refer to the principle of progressive realisation, the concept of "maximum available resources" and the principle of non-retrogression, such references again predictably occur within the framework of broader economic and budgetary considerations and specifically in light of how such concepts are applicable in times of economic crises (ibid.: paras. 29-31). While these represent significant implementation reminders given the important role which public budgeting plays in the progressive realisation of children's rights, it is necessary to recollect that budgeting alone is not tantamount to progressive realisation. Rather, it forms a crucial component along the continuum of improvement which progressive realisation compels. The danger with elevating public budgeting as the sole and exclusive metric against which to determine the allocation of resources or the extent to which states are fulfilling their socio-economic commitments is that non-fiscal and indeed qualitative resources are not only marginalised, but arguably dismissed altogether. Thus, when considered together, the limitations of both GC s No. 5 and No. 19 regarding the application of the principle of progressive realisation become evident.

\subsection{The Failure to Consider Progressive Realisation within the CRC Committee's Reporting Process}

The final reason which compels a revision of GC No. 5 is the CRC Committee's failure to consider progressive realisation within its reporting system and the concluding observations issued thereunder. Treaty monitoring bodies have previously been described as standing at the heart of the international human 
rights protection system as engines translating universal norms into social justice and individual well-being' (UNGA, 2012: 7). From a children's rights perspective, Article 44, CRC prescribes the function of the CRC's reporting system which is 'to provide the Committee with a comprehensive understanding of the implementation of the Convention in the country concerned' (Article $44(2))$. This process has further been elaborated by Lansdown as intending 'to promote social mobilisation and encourage government officials, non-governmental organisations (NGOs) and others to work collaboratively to realise children's rights' (Lansdown, 2000: 114). Furthermore, through its detailed reporting guidelines, the Committee have delineated the format of such reports (CRC, 2015), with considerable attention unsurprisingly accorded to the CRC's general measures of implementation (ibid.: paras. 18-21). However, despite the wide-ranging nature of the guidance which falls under the general measures of implementation, no reference is made to progressive realisation, despite the Committee having previously stated that the second sentence of Article 4, CRC introduces the principle. While the guidance contains important directions pertaining to the need for states to evidence legislative conformity with the CRC, the delineation of governmental control for matters relating to children's rights, whether a national children's strategy has been implemented and the extent to which domestic budgetary allocations relate to the implementation of children's rights, amongst others, the failure to allude to progressive realisation deprives the CRC Committee of an important investigative and evidential standard against which to monitor and track state compliance regarding children's socio-economic rights.

An examination of the recent concluding observations issued by the CRC Committee would appear to suggest that the principle of progressive realisation neither influences nor underpins the Committee's adjudicative remarks within their concluding observations. This can be seen from the most recent corpus of observations issued by the Committee and which include their comments on the performance of the Federated States of Micronesia, ${ }^{4}$ the Cook Islands, ${ }^{5}$ Tuvalu, ${ }^{6}$ the State of Palestine, ${ }^{7}$ Austria, ${ }^{8}$ Costa Rica, ${ }^{9}$ Hungary, ${ }^{10}$ Belarus, ${ }^{11}$

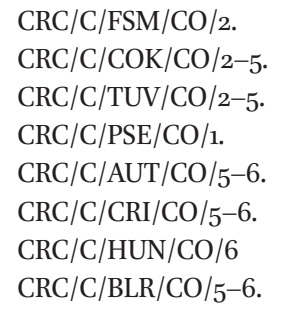


Rwanda, ${ }^{12}$ Portugal, ${ }^{13}$ Mozambique, ${ }^{14}$ Australia, ${ }^{15}$ Bosnia Herzegovina, ${ }^{16}$ the Republic of Korea ${ }^{17}$ and Cote D'Ivoire. ${ }^{18}$ All of the concluding observations issued pursuant to an examination of the aforementioned states reveal a failure by the Committee to engage with progressive realisation. While each state understandably retains its own margin of appreciation in terms of what measures it selects to implement the Convention, the purpose of progressive realisation is not to displace or supplant such discretion but rather, 'to facilitate and frame a dialogue within a state with respect to the discretion and speed at which the state should pursue measures to secure the implementation of economic, social and cultural rights' (Tobin, 2019: 112). Indeed, the principle's omission from the reporting guidelines and consequently from the purview of the Committee's examination ultimately divests it of an important accountability function which is that it could provide a legal hook upon which to assess state compliance regarding the implementation of their socio-economic commitments.

Take, for example, the Committee's recent comments regarding the implementation of the right to health for the Federated States of Micronesia. Although expressing concern regarding issues pertaining to access to healthcare facilities for those in rural areas, the high mortality rate of children under five years of age, the low level of vaccination coverage within the state, the unavailability of reliable health data and the limited access to reproductive and sexual health care services for adolescents (CRC Committee, 2020: para. 50-54), the Committee's comments would arguably carry more persuasive and legal authority if framed in the language of progressive realisation and non-retrogression rather than framed in the non-binding language of "concern". This is not to say that concern is not warranted. Rather, such concern should form the basis for a more authoritative engagement with progressive realisation. Similarly, the Committee's observations regarding Austria's implementation of the right to education further reveals their disengagement with the principle of progressive realisation. Despite Article 28(1), CRC explicitly requiring states to "progressively" realise the right to education, the Committee's comments that Austria 'strengthen' (CRC Committee, 2020: para. 37) children's access to free primary and secondary education in addition to strengthening access

\footnotetext{
$12 \mathrm{CRC} / \mathrm{C} / \mathrm{RWA} / \mathrm{CO} / 5^{-6}$.

$13 \mathrm{CRC} / \mathrm{C} / \mathrm{PRT} / \mathrm{CO} / 5^{-6}$.

$14 \mathrm{CRC} / \mathrm{C} / \mathrm{MOZ} / \mathrm{CO} / 3^{-4}$.

$15 \mathrm{CRC} / \mathrm{C} / \mathrm{AUS} / \mathrm{CO} / 5^{-6}$.

$16 \mathrm{CRC} / \mathrm{C} / \mathrm{BIH} / \mathrm{CO} / 5^{-6}$.

$17 \mathrm{CRC} / \mathrm{C} / \mathrm{KOR} / \mathrm{CO} / 5^{-6}$.

$18 \mathrm{CRC} / \mathrm{C} / \mathrm{CIV} / \mathrm{CO} / 2$.
} 
to inclusive education for those with disabilities represents a clear departure from the legal standard set down in Article 28(1). Indeed, their tendency to invoke the phrase "strengthen" is evident also from their observations on both Hungary's (CRC 2020, para. 40) and Portugal's (CRC 2020, para. 36(c)) implementation of the right to education. This potentially not only dilutes the obligations of states to progressively realise children's education rights but signifies a practice whereby the Committee appears willing to further distance itself from the principle of progressive realisation, if not disapply the principle itself.

Equally absent from the above-mentioned concluding observations was any discussion of the corresponding principle of non-retrogression. Despite implicitly falling under Article 4, CRC and by extension within the general measures of implementation, it too was overlooked within the reporting process. If properly considered, non-retrogression could potentially assume an important evidential role, in that any backsliding in the enjoyment of children's rights would have to be rigorously justified and subject to examination by the Committee. Considering the foregoing, it is contended that a revised General Comment on the General Measures of Implementation to give effect more visibly to the principle of progressive realisation could enhance the quality and strength of the CRC's reporting process. Updating GC No. 5 would also arguably necessitate a revision of the existing reporting guidelines to subsume progressive realisation and its related facets within its explanatory guidance. Such updates could also lead to more robust, evidence-based and legally rigorous analysis by the Committee. Indeed, an express reference to and elaboration of progressive realisation within an updated GC No. 5 would arguably, not only arrest the principle's current marginalisation by the CRC Committee, but contribute enormously to the prospective enhancement and effective delivery of children's socio-economic rights.

\section{Conclusion}

In seeking to reclaim the potential which progressive realisation can and should possess within children's rights law, this article has sought to highlight the need for the CRC Committee to reconnect more meaningfully with the principle and reclaim its true legal potential. By isolating the multi-dimensional aspects which both comprise and guide the principle's application, it has argued that the CRC Committee have not only disengaged with this important legal principle, but have peripheralised it in both their General Comments and the reporting process. By advocating for the promulgation of an updated GC on the general Measures of Implementation, this article has sought not 
only to uncover the shortcomings in the Committee's current practice, but to advance a way in which those shortcomings can be overcome.

Children's rights now stand at an unprecedented juncture: wedged between the aftereffects of the 2008 global financial crisis and the imminent economic, social and political repercussions yet to fully transpire as a result of the global spread of Covid-19 (UN, 2020). Against this canvas, children's rights scholarship and practice must reclaim the principle of progressive realisation to ensure children's socio-economic rights are not reduced to mere aspirational reflections moving forward. In this regard, Leckie's (1998) appeal for, 'New interpretations of this principle ... to be developed in order to widen the legal vision of public officials and courts to reflect the view that states must move as expeditiously as possible towards the realisation" (ibid:: 94) of such rights retains much currency in today's global context. By revising GC No. 5, progressive realisation can become a durable and persuasive principle within children's rights law to examine, challenge and reorganise how states comply with their socio-economic rights commitments. Indeed, if children's rights are to confront the challenges and demands of an ever-changing world, then new approaches are evidently required. By reclaiming its true potential, the principle of progressive realisation can represent much more than an abstractive theoretical idiom within children (and human) rights law and become an important legal hook upon which to hold states accountable for their actions.

\section{References}

Abramson, B., A Commentary on the United Nations Convention on the Rights of the Child, Article 2 The Right of Non-Discrimination (Martinus Nijhoff Publishers, 2008). Alston, P., (2010) The General Comments of the UN Committee on Economic, Social and Cultural Rights, American Society of International Law Proceedings 2010, Vol. 104, 4-7.

Balakrishman, R. et al., Maximum Available Resources \& Human Rights (Centre for Women's Global Leadership: New Jersey, 2011).

Besson, S., "The Principle of Non-Discrimination in the Convention on the Rights of the Child", The International Journal of Children s Rights 2005 (13), 433-461.

Bilchitz, D., "Towards a Reasonable Approach to the Minimum Core: Laying the Foundations For future Socio-Economic Rights Jurisprudence", 19 South African Journal of Human Rights 2003, 1-26.

Bilchitz, D., "Socio-economic rights, economic crisis, and legal doctrine", International Journal of Constitutional Law 2014 Vol. 12 (3), July 2014, 710-739. 
Bodig, M., "Tracing the Roles of Soft Law in Human Rights" in Lagoutte, S., GammeltoftHansen, T. and Cerone, J. (eds.), Soft Law, Doctrinal Development, and the General Comments of the UN Committee on Economic, Social and Cultural Rights (Oxford: Oxford University Press, 2016), 69-88.

Chairperson of the CESCR, "Letter Dated 16 May 2012 Addressed by the Chairperson of the Committee on Economic, Social and Cultural Rights to States Parties to the International Covenant on Economic, Social and Cultural Rights", (2012) UN Doc $\mathrm{HRC} / \mathrm{NONE} / 2 \mathrm{O12} / 76$, UN reference CESCR/48th/SP/MAB/SW.

Committee on the Rights of the Child (21 September 2007), General Discussion on "Resources for the Rights of the Child - Responsibility of States", 46th Session.

Committee on the Rights of the Child, The Aims of Education (United Nations, 2001). Original edition.

Committee on the Rights of the Child (2003), General Comment No. 5, General measures of Implementation of the Convention on the Rights of the Child.

Committee on the Rights of the Child (2013), General Comment No. 15 on the right of the child to have his or her best interests taken as a primary consideration (Art 3 , para. 1).

Committee on the Rights of the Child (2016), General Comment No. 19 on public budgeting for the realization of children's rights (Art. 4).

Committee on the Rights of the Child (2019), Concluding observations on the combined fifth and sixth periodic reports of Portugal, CRC/C/PRT/CO/5-6.

Committee on the Rights of the Child (2020), Concluding observations on the second periodic report of the Federated States of Micronesia, CRC/C/CO/FSM/CO/2.

Committee on the Rights of the Child (2020), Concluding observations on the combined fifth and sixth periodic reports of Austria, CRC/C/AUT/CO/5-6.

Committee on the Rights of the Child (2020), Concluding observations on the sixth periodic report of Hungary, $\mathrm{CRC} / \mathrm{C} / \mathrm{HUN} / \mathrm{CO} / 6$.

Committee on the Rights of the Child, Initial reports of states parties due in 1994, 28 March 1994, CRC/C/11/Add.1.

Craven, M., The international covenant on economic, social and cultural rights: a perspective on its development (Oxford: Clarendon Press, 1995).

Dowell-Jones, M., "The Economics of the Austerity Crisis: Unpicking Some Human Rights Arguments", Human Rights Law Review 2015 (15), 193-223.

Eide, A. et al., Economic, Social and Cultural Rights, Martinus Nijhoff Publihsers, 1995).

Fakuda-Parr, S. et al., Fulfilling Social and Economic Rights (Oxford University Press, 2015).

Felner, E., “Closing the 'Escape Hatch': A Toolkit to Monitor the progressive Realization of Economic, Social and Cultural Rights", Journal of Human Rights Practice, 2009 $(1(3)), 402-435$. 
Fisher, Angelina, Minimum Core and the Right to Education, World Bank, Washington, DC (C) World Bank, 2017: https://openknowledge.worldbank.org/handle/1og86/29142 License: CC BY 3.o IGO.

Forman, L., Caraoshi, C., Chapman, Audrey, R. and Lamprea, E., "Conceptualising minimum core obligations under the right to health: How should we define and implement the "morality of the depths", The International Journal of Human Rights, $2016(20(4)), 531-548$.

Fredman, S., Comparative Human Rights Law (Oxford University Press, 2018).

Gerber et al., General Comment No. 16 on State Obligations Regarding the Impact of the Business Sector on Children's Rights: What is its Standing, Meaning and Effect?, Melbourne Journal of International Law 2013 (14), 1-36.

Human Rights Committee, General Comment No. 18, Non-discrimination (37th session, 1989), Compilation of General Comments and General Recommendations. Adopted by Human Rights Treaty Bodies, U.N. Doc. HRI/GEN/1/Rev.1 at 26 (1994).

International Law Association, Final Report on the Impact of Findings of the United Nations Human Rights Treaty Bodies (presented at the Berlin Conference 2004: International Human Rights Law and Practice).

Kalantry, Sital, Getgen, Jocelyn E. and Koh, Steven A., "Enhancing Enforcement of Economic, Social, and Cultural Rights Using Indicators: A Focus on the Right to Education in the ICESCR", 2010, Cornell Law Faculty Publications, Paper 1076: http://scholarship.law.cornell.edu/facpub/1076.

Karimova, T., The Nature and Meaning of 'International Assistance and Cooperation' under the International Covenant on Economic, Social and Cultural Rights, in Riedel, E., Giacca, G., \& Golay, C., (eds.) Economic, Social and Cultural Rights in International Law (Oxford University Press, 2014).

Kendrick, A., "Measuring compliance: social rights and the maximum available resources dilemma", Human Rights Quarterly 2017 (39(3)).

Kilkelly, U., \& Liefaard, T.(eds.) International Human Rights of Children, (Springer: Singapore).

Lansdown, G., "The Reporting Process Under The Convention On The Rights Of The Child" in Alston, P. and Crawford, J. (eds.,), The Future of UN Human Rights Treaty Monitoring (Cambridge University Press, 2000).

Leckie, S., "Another Step Towards Indivisibility: Identifying the Key Features of Violations of Economic, Social and Cultural Rights", Human Rights Quarterly 1998 (20), 81-124.

Lehmann, K., "In Defense of the Constitutional Court: Litigating Socio-Economic Rights and the Myth of the Minimum Core", American University International Law Review 222006 (1), 163-197. 
Liefaard, T., \& Doek, J., (eds.) Litigating the Rights of the Child: The UN Convention on the Rights of the Child in Domestic and International Jurisprudence (Springer, 2014).

Limburg Principles on the Implementation of the International Covenant on Eeconomic, Social and Cultural Rights (1987).

Lundy, L., "Mainstreaming children's rights in, to and through education in a society emerging form conflict", The International Journal of Children's Rights 2006 (14(4)), 331-35 .

Lundy, L. and Byrne B., "The Four General Principles of the United Nations Convention on the Rights of the Child: The Potential Value of the Approach in Other Areas of Human Rights Law" in Brems E., Desmet E., and Vandenhole W. (eds.), Children's Rights Law in the Global Human Rights Landscape: Isolation, Inspiration, Integration (Routledge, 2017).

Lundy, L., and O'Lynn, P., "Education Rights" in The Human Rights of Children, Kikelly U., and Liefaard E. (eds.) (Springer, 2019).

Lundy, T., Children's rights and educational policy in Europe: the implementation of the United Nations Convention on the Rights of the Child, Oxford Review of Education 2012, Vol. 38. No. 4.

Maastricht Guidelines on Violations of Economic, Social and Cultural rights (1997), MacNaughton, G. and Frey, D. (eds.), Economic and Social Rights in a Neoliberal World (Cambridge University Press, 2018).

McCall-Smith, K., "Interpreting international human rights standards: Treaty body general comments as a chisel or hammer?" in Lagoutte S., Gammeltoft Hansen T. and Cerone J. (eds.), Tracing the Role of Soft Law in Human Rights (Oxford University Press, 2016).

Moyn, S., Not enough: Human Rights in an Unequal World (Harvard University Press, 2018).

Murphy, Mary P., "Maximising available resources: Equality and human rights proofing Irish fiscal policy," Administration, Sciendo, 2017 (65(3)), 59-8o.

Nolan, A., Economic and Social Rights, Budgets and the Convention on the Rights of the Child. The International Journal of Children's Rights, 2013 21(2), 248-277.

Nolan, A. and Dutschke, M., "Article 2(1) ICESCR and States Parties' Obligations: Whither the Budget?", European Human Rights Law Review 2010 (3), 28o-289.

Nolan, A. et al., "Two steps forward, no steps back? Evolving Criteria on the prohibition of retrogression in economic and social rights" in Nolan A. (ed.), Economic and Social Rights After the Global Financial Crisis (Cambridge University Press, 2014).

Nolan, A., "Privatization and Economic and Social Rights", Human Rights Quarterly $2018(80(4)), 815^{-858 .}$

O'Connell, P. et al., Applying an International Human Rights Framework to State Budget Allocations (Taylor and Francis, 2014). 
Palmer, E., Judicial review, socio-economic rights and the Human Rights Act (Oxford: Hart Publishing, 2007).

Palmer, E., "Protecting Socio-Economic Rights Through the European Convention on Human Rights: Trends and Developments in the European Court of Human Rights", Erasmus Law Review 2009 (2(4)), 397-425.

Peleg, N., International Children's Rights Law: General Principles', in Kilkelly U; Liefaard $\mathrm{T}$ (ed.), International Human Rights of Children, Springer 2018, pp. 135-158.

Porter, B., 'Rethinking Progressive Realization: How Should it be Implemented in Canada?' Background Paper for a Presentation to the Continuing Committee of Officials on Human Rights, (Social Rights Advocacy Centre, 2015).

Report of the United Nations High Commissioner for Human Rights, 25 June 2007, United Nations Economic and Social Council, E/2007/82.

Robertson, Robert E., "Measuring State Compliance with the Obligation to Devote the 'Maximum Available Resources' to Realizing Economic, Social and Cultural Rights", Human Rights Quarterly 1994 (16(4), 693-714.

Russell, S. and Chapman, A., Core Obligations: Building a Framework for Economic, Social and Cultural Rights (Intersentia, 2002).

Saiz, I., Rights in Recession? Challenges for Economic and Social Rights Enforcement in Times of Crisis, Journal of Human Rights Practice, 2009, Volume 1, Issue 2, pp. 277-293.

Sepúlveda, M., The Nature of the Obligations under the International Covenant on Economic, Social and Cultural Rights (Intersentia, 2003).

Sepulveda, M., Obligations of international assistance and cooperation in an optional protocol to the international covenant on economic, social and cultural rights. Netherlands Quarterly of Human Rights, 2006, 24(2), 271-304

Shields, Kirsteen, The Minimum Core Obligations of Economic, Social, and Cultural Rights: The Rights to Health and Education, World Bank, Washington, DC, 2017. (C) World Bank: https://openknowledge.worldbank.org/handle/10986/29145 License: CC BY 3.0 IGO.

Skogly, S., "The requirement of using the 'maximum available resources' for human rights realisation: a question of quality as well as quantity?" Human Rights Law Review 2012 (12(3)), 393-420.

Ssenyonjo, M., "Reflections on state obligations with respect to economic, social and cultural rights in international human rights law", The International Journal of Human Rights Law 2011 (15(6), 969-1012.

Stalford, H., The Price is Rights!: Cost Benefit Analysis and the Resourcing of Children's Services, Children and Youth Services Review, 2019.

Stalford, H. and Byrne, S., "Human Rights, Children's Rights, and the Family" in Ruth L. (ed.), Family law (Oxford University Press, 2018). 
Tasioulas, John, World Bank, Washington, DC. (c) World Bank, 2017: https:// openknowledge.worldbank.org/handle/1og86/29144 License: CC BY 3.o IGO.

Tobin, J., The UN Convention on the Rights of the Child: A Commentary. (Oxford University Press, 2019).

Tomasevski, K., Human rights obligations: making education available, accessible, acceptable and adaptable, Right to Education Primers, 2001, No.3 (Right to Education Initiative).

UN (1993) Vienna Declaration and Programme for Action, Adopted by the World Conference on Human Rights in Vienna on 25 June 1993.

UN Committee on the Rights of Persons with Disabilities, General comment No. 6 (2018) on equality and non-discrimination, CRPD/C/GC/6.

UN Committee on Economic, Social and Cultural Rights (CESCR), General Comment No. 13: The Right to Education (Art. 13 of the Covenant), 8 December 1999, E/C.12/1999/10.

UN General Assembly, Convention on the Rights of the Child, 20 November 1989.

UN Committee on the Rights of the Child (2015) Treaty-specific guidelines regarding the form and content of periodic reports to be submitted by States parties under article 44, paragraph 1 (b), of the Convention on the Rights of the Child, (3 March 2015) CRC/C/58/Rev.3

UN Committee on the Rights of the Child (CRC), General comment No. 8 (2006): The Right of the Child to Protection from Corporal Punishment and Other Cruel or Degrading Forms of Punishment (Arts. 19; 28, Para. 2; and 37, inter alia), 2 March $2007, \mathrm{CRC} / \mathrm{C} / \mathrm{GC} / 8$

UN Office of the High Commissioner for Human Rights (OHCHR), Strengthening the United Nations human rights treaty body system: A report by the United Nations High Commissioner for Human Rights, June 2012

UNICEF (2013) Children's Rights Impact Assessments: A guide for integrating children's rights into impact assessments and taking action for children, UNICEF (Geneva) and the Danish Institute for Human Rights, (Copenhagen)

United Nations (2020), Policy Brief: The Impact of Covid-19 on Children, 15 April 2020.

United Nations, Committee on Economic, Social and Cultural Rights, General Comment No. 3, The nature of States parties obligations (Art. 2, para. 1) (1990).

United Nations Committee on the Rights of the Child (2016), Concluding observations on the combined third to fifth periodic reports of Nepal, CRC/C/NPL/3-5, 8 July 2016.

United Nations Committee on the Rights of the Child (2020), CRC Covid-19 Statement. United Nations, Economic and Social Council, Progress report of the Special Rapporteur on the right to education, Katarina Tomasevski, submitted in accordance with Commission on Human Rights resolution 1999/25 (1 February 200o). 
United Nations Economic and Social Council, Statement on the coronavirus disease (COVID-19) pandemic and economic, social and cultural right, E/C.12/2020/, 17 April 2020.

Vandenhole, W., "Economic, Social and Cultural Rights in the CRC: Is There a Legal Obligation to Cooperate Internationally for Development?", The International Journal of Children's Rights 2009 (17(1), 23-63.

Verhellen, E., "Children's Rights in Europe”, The International Journal of Children's Rights 1993 (1), 357-376.

Vierdag, E.W., "The Legal Nature of the Rights Granted by the International Covenant on Economic, Social and Cultural Rights", Netherlands Yearbook of International Law, 1978, vol. IX, 69-105.

Warick. Ben T. C., (2019) "Unwinding Retrogression: Examining the Practice of the Committee on Economic, Social and Cultural Rights", Human Rights Law Review 2019 (19), 467-49o.

Warwick, Ben T. C., "A Hierarchy of Comfort? The CESCR's Approach to the 2008 Crisis" in MacNaughton G. and Frey D. (eds.), Economic and Social Rights in a Neoliberal World (Cambrige University Press, 2018).

Wills, Joe J. and Warwick, Joe J., "Contesting Austerity: The Potential and Pitfalls of Socioeconomic Rights Discourse”, Indiana Journal of Global Legal Studies 2016 (23(2)), 629-664.

Young, Katherine G., "The Minimum Core of Economic and Social Rights: A Concept in Search of Content", Yale International Law Journal 2008 (33): 113-175.

Young, Katherine G., Constituting Economic and Social Rights (Oxford University Press, 2012). 